\title{
High-performance liquid chromatographic analysis of bioactive quinones from Auxemma glazioviana
}

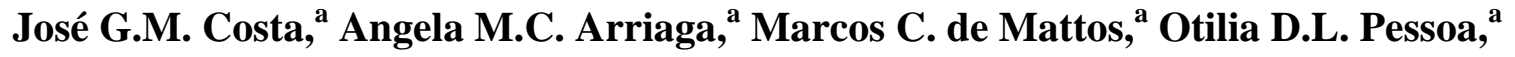 \\ Ronaldo F. Nascimento, ${ }^{b}$ and Telma L.G. Lemos ${ }^{a} *$ \\ ${ }^{a}$ Departamento de Química Orgânica e Inorgânica, Universidade Federal do Ceará, CP 12200, \\ CEP 60451-970, Fortaleza-Ceará-Brazil \\ ${ }^{b}$ Departamento de Química Analítica e Físico-Química, Universidade Federal do Ceará, CP \\ 12100, CEP 60451, Fortaleza-Ceará-Brazil \\ E-mail: tlemos@dqoi.ufc.br
}

\section{Dedicated to Professor Otto Richard Gottlieb on the occasion of his $85^{\text {th }}$ birthday}

(received 19 Jan 04; accepted 01 Aug 04; published on the web 02 Aug 04)

\begin{abstract}
Chemical constituents obtained from ethanol extract of Auxemma glazioviana, a very common tree of Ceará State-Brazil, were analyzed and quantified by reverse-phase HPLC. To evaluate the quinone content of the extract, a simple, rapid and accurate high-performance liquid chromatography (HPLC) method was developed for the assessment of three bioactive quinones: glaziovianol 1, oncocalyxone A 2 and oncocalyxone C 3. The HPLC system used a Shimadzu octadecylsilyl silica (ODS) column with acetonitrile and water $(1: 1, \mathrm{v} / \mathrm{v})$, as the mobile phase and detection at $280 \mathrm{~nm}$. Quantitative analysis showed that 2 is the most abundant compound in both extracts EtOAc and $\mathrm{CHCl}_{3}$, with 35.9 and 39.9\%, followed by 1 with 22.8 and $26.2 \%$, respectively.
\end{abstract}

Keywords: Auxemma glazioviana, Boraginaceae, Cordiachrome, HPLC quantification, glaziovianol, oncocalyxone A

\section{Introduction}

Auxemma glazioviana (Boraginaceae) popularly know as "pau branco louro" is a typical tree of Ceara State, Brazil. ${ }^{1}$ Their barks have been used in folk medicine as cicatrizant. This biological activity probably can be attributed to the high content of allantoin. ${ }^{2}$ Phytochemical analysis of the ethanol extract of heartwood allowed the isolation of terpenoid quinones, characterized as cordiachromes, identified as glaziovianol 1, oncocalyxone A 2 and oncocalyxone C 3. ${ }^{3-5}$ Cordiachromes are meroterpenoids benzoquinones found in several species of Cordia ${ }^{6,7}$ and 
Auxemma. ${ }^{3-5}$ Compound 2 is an 1,4-antracenedione named oncocalyxone A, with a very intensive wine-red pigment found in high content in the heartwood of Auxemma species. This compound showed several biological activities including anticarcinogen, inhibition of platelet, toxicity to sea urchin egg and antioxidant. ${ }^{8-11}$

The presence of this rare group of compounds and their pharmacological activities, lead us to develop an accurate high-performance liquid chromatography (HPLC) method for the quality assessment of the heartwood of A. glazioviana. There is a few reports about the HPLC quantification of quinones in plants extracts available, except the determination of naphthoquinones in Arnebia densifloria. ${ }^{12}$ High performance liquid chromatography had never been employed for the quantitative determination of cordiachromes in A. glazioviana. The contents of quinones 1, 2 and 3, using isocratic elution and reversed-phase systems, with great resolution and short time analysis, has been determined to demonstrate the robustness of the established method. This methodology can be appropriately used to identify others quinones presents in Auxemma, Cordia species.

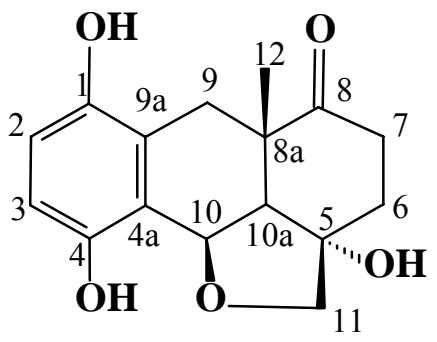

( 1 )<smiles>COC1=CC(=O)C2=C(C1)C(=O)C(=O)C=C2CO</smiles><smiles>CCOC(O)[C@H]1CC[C@@H](O)[C@]2(C)CC3=C(C(=O)C=C(OC)C3=O)[C@H](O)[C@H]12</smiles>

\section{Results and Discussion}

Benzoquinones 1, 2 and 3 isolated from A. glazioviana heartwood were well determined and quantified by RP-HPLC in isocratic conditions and short time analyses (10 min). A typical chromatogram of a chloroform extract is shown in Figure 1, which illustrates the separation of the three phytochemicals, while a chromatogram of a mixture of isolated compounds is represented in Figure 2. The peaks in the chromatogram of extracts were identified based on the retention time of standards injected separately and by addition of standard solutions. The peaks 
with retention times about 3.0, 3.9 and 5.4 min. correspond to glaziovianol 1, oncocalyxone A 2 and oncocalyxone $\mathrm{C} \mathbf{3}$, respectively.

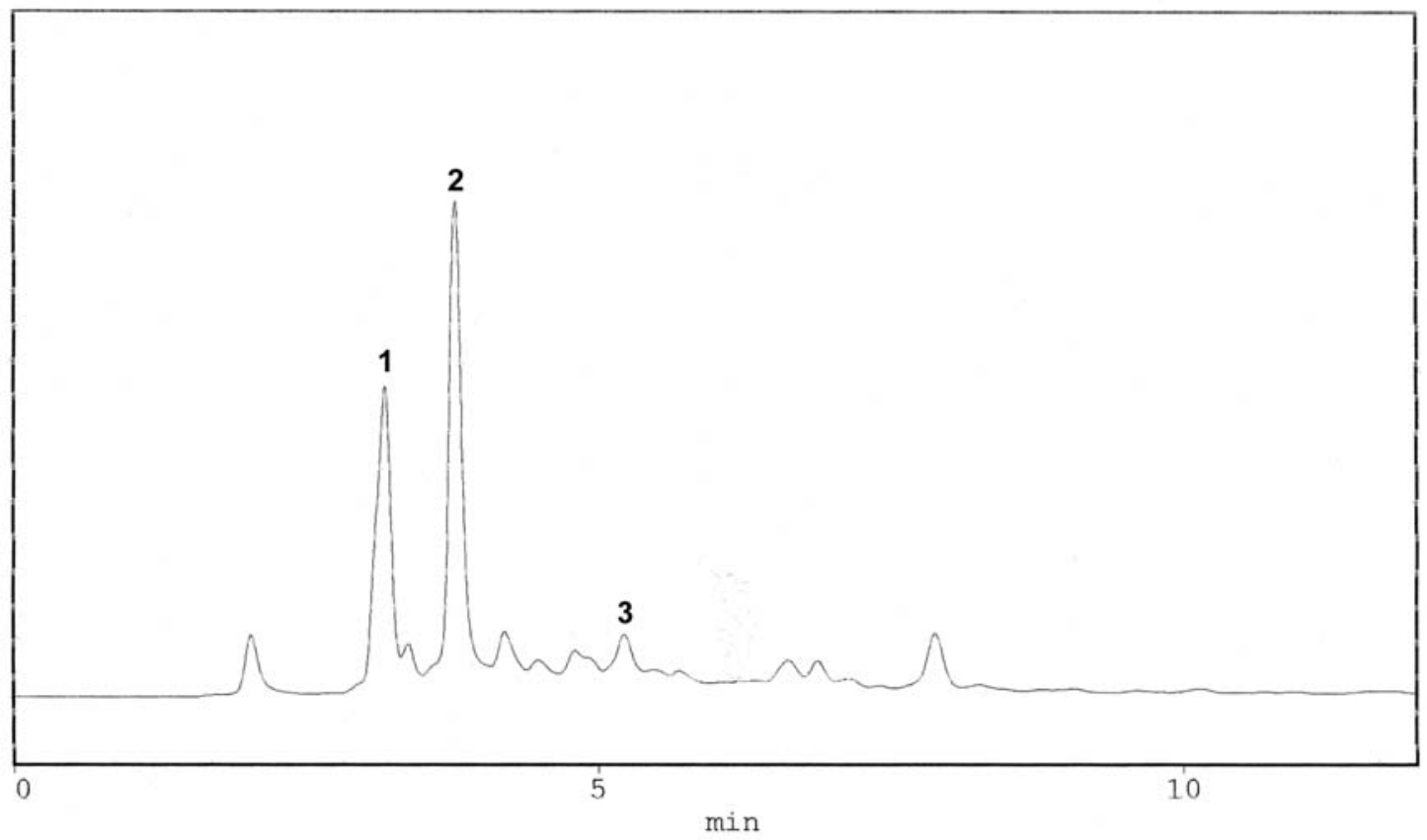

Figure 1

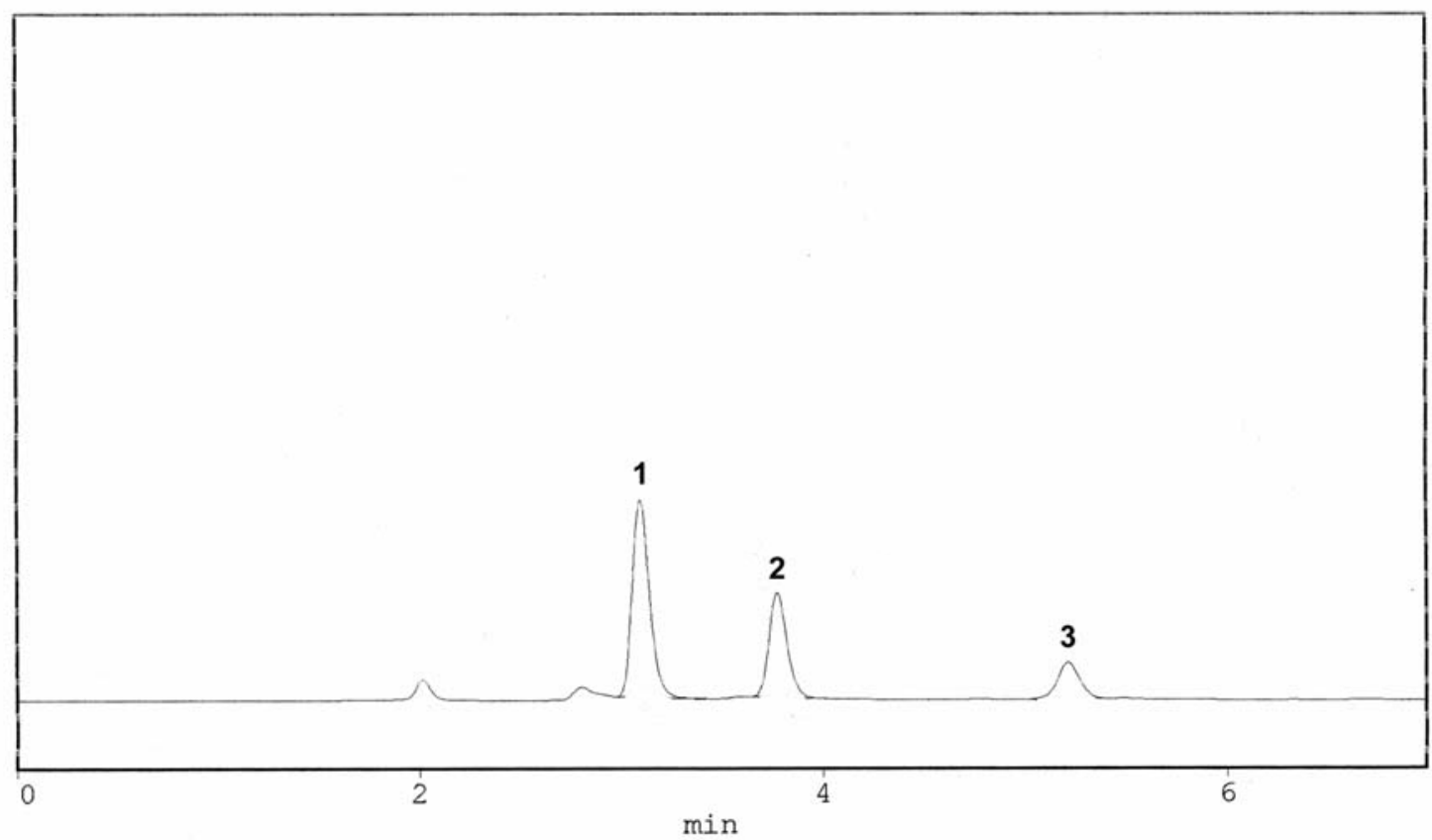

Figure 2 
Quantitative analysis of the $\mathrm{CHCl}_{3}$ and EtOAc extracts showed that oncocalyxone A 2 is the most abundant compound, with 39.9 and 35.9\%, followed by glaziovianol 1 with 26.2 and $22.8 \%$, respectively (Table 1 ).

Table 1. Content of cordiachromes in the extracts of A. glazioviana by external calibration method

\begin{tabular}{ccccc}
\hline Compound & \multicolumn{2}{c}{$\mathrm{CHCl}_{3}$ extract } & \multicolumn{2}{c}{ EtOAc extract } \\
\hline & $\mathrm{mg} / \mathrm{L}$ & $\%$ & $\mathrm{mg} / \mathrm{L}$ & $\%$ \\
$\mathbf{1}$ & 28.02 & 26.20 & 35.26 & 22.80 \\
$\mathbf{2}$ & 39.88 & 39.88 & 35.91 & 35.91 \\
$\mathbf{3}$ & 21.35 & 15.50 & 16.04 & 18.40 \\
\hline
\end{tabular}

Linear regression equations, corresponding to maximum absorption wavelength, $280 \mathrm{~nm}$, of three compounds, were formulated as 1: $y=62893+8437 x(r=0.999) ; 2: y=202074+2182 x$ $(r=0.999)$; $3: y=237894+45683 x(r=0.999)$, where $y$ is the integration unit and $x$ is the concentration $(\mathrm{mg} / \mathrm{L})$ of cordiachromes.

The validation of method was ascertained by study of the reproductibility and recovery by carrying out five assays on the same sample which was injected twice on the same day and over a 2-day period analysis. The values of relative standard deviations (R.S.D.) were low and the coefficients of three constituents ranged between 0.17 and $1.72 \%$, as can be seen in Table 2 .

Table 2. Reproductibility of the HPLC analysis of cordiachromes $\mathbf{1}, 2$ and 3 in $\mathrm{CHCl}_{3}$ and EtOAc extracts (concentration in $\mathrm{mg} / \mathrm{L}$ )*

\begin{tabular}{ccc}
\hline Compound & Concentration $(\mathrm{mg} / \mathrm{L}) \pm \mathrm{SD}$ & $\mathrm{RSD}(\%)$ \\
\hline $\mathbf{1}$ & $25.68 \pm 0.42$ & 1.63 \\
$\mathbf{2}$ & $40.58 \pm 0.70$ & 1.72 \\
$\mathbf{3}$ & $20.74 \pm 0.04$ & 0.17 \\
\hline
\end{tabular}

$* \mathrm{n}=5$, injections were performed in duplicate.

The experimentally found recoveries where amounts added known of the patterns on the sample with concentration also well known are given in Table 3. As can be seen, the values are in the range of $92.86-100.30 \%$. 
Table 3. Recoveries of cordiachromes 1, 2 and 3 added to $\mathrm{CHCl}_{3}$ and EtOAc extracts (concentration in $\mathrm{mg} / \mathrm{L}$ )*

\begin{tabular}{ccccc}
\hline Compound & $\begin{array}{c}\text { Concentration } \\
\text { present }\end{array}$ & $\begin{array}{c}\text { Concentration } \\
\text { added }\end{array}$ & $\begin{array}{c}\text { Concentration } \\
\text { found }\end{array}$ & $\begin{array}{c}\text { Recovery } \\
(\%)\end{array}$ \\
\hline $\mathbf{1}$ & 14.01 & 6.87 & $19.39 \pm 0.78$ & $92.86 \pm 3.70$ \\
& & 12.90 & $26.31 \pm 0.87$ & $97.70 \pm 3.20$ \\
$\mathbf{2}$ & \multirow{2}{*}{19.94} & 18.50 & $35.70 \pm 0.59$ & $100.30 \pm 1.70$ \\
& & 6.53 & $26.12 \pm 0.11$ & $98.62 \pm 0.40$ \\
& \multirow{3}{*}{3} & 15.65 & $32.80 \pm 0.11$ & $97.93 \pm 0.30$ \\
& \multirow{2}{*}{10.68} & 13.55 & $43.90 \pm 1.232$ & $98.74 \pm 2.70$ \\
& & 8.74 & $19.34 \pm 0.31$ & $99.56 \pm 1.60$ \\
& & 20.76 & $25.69 \pm 0.28$ & $97.62 \pm 1.10$ \\
& & 24.52 & $9.38 \pm 0.09$ & $97.06 \pm 3.80$ \\
\hline
\end{tabular}

$* \mathrm{n}=5$, injections were performed in duplicate.

Thus, cordiachromes isolated in relatively high amounts from heartwood of A. glazioviana were determined quantitatively, using HPLC. The method described here has not only provided good separation and precision, but has also been found to be less time-consuming due to the suitability of the polarities of eluents, column selectivity and other conditions under which the experiments were conducted, and may therefore be used in quantitative evaluation of cordiachromes and derivatives contained in others plants.

The compounds mentioned in this paper, can be successfully separated within just $10 \mathrm{~min}$. by reversed-phase chromatography in isocratic elution with a $\mathrm{C}-18$ column and $\mathrm{CH}_{3} \mathrm{CN} / \mathrm{H}_{2} \mathrm{O}(1: 1$, $\mathrm{v} / \mathrm{v}$ ) mobile phase, in detection UV at $280 \mathrm{~nm}$.

Quantitative analysis showed that 2 is the most abundant compound in the $\mathrm{CHCl}_{3}$ and EtOAc extracts analyzed, with 39.8 and $35.9 \%$, respectively.

In conclusion, the newly established HPLC method is validated for the quantification of the main bioactive quinones $\mathbf{1}, 2$ and 3, and the quality control of the plant material such as A. glazioviana where quinones are the dominant phytochemicals.

This method is rapid, precise, reproducible, sample-saving and maybe helpful for the quantitative analysis of phytochemical analogous to the quinones.

\section{Experimental Section}

General Procedures. The analyses were carried out on a HPLC (Shimadzu), model - LC/10AD, equipped with an injector $-20 \mu \mathrm{L}$ loop (Shimadzu). HPLC experiments were conducted using a Shimadzu C-18 column ( $5 \mu \mathrm{m}$ particle size, $250 \mathrm{~mm} \times 4,6 \mathrm{~mm} \mathrm{I}$. D.) with a flow rate of $1 \mathrm{~mL} / \mathrm{min}$ at room temperature. The mobile phase used was $\mathrm{CH}_{3} \mathrm{CN} / \mathrm{H}_{2} \mathrm{O}(1: 1$, v/v), with elution 
isocratic and UV detection (SPD-10A/UV-VIS) at $280 \mathrm{~nm}$. Acetonitrile used were of HPLC grade (Sigma/Aldrich) and were degassed in an ultrasonic bath before use. The water was distilled using a Milli-Q system (Millipore) and mobile phase filtered through a $0.49 \mu \mathrm{m}$ nylon filter. NMR spectra were recorded on a Bruker DRX 500 spectrometer operating at $500 \mathrm{MHz}$ for proton and $125 \mathrm{MHz}$ for ${ }^{13} \mathrm{C}$ spectra. IR spectra were run on a Perkin-Elmer $1000 \mathrm{FT}$-IR spectrometer using $\mathrm{KBr}$ pellets. Melting points were determined on a Mettler FP5 apparatus and are uncorrected. EIMS data were obtained at $70 \mathrm{eV}$ on a VG-auto spec mass spectrometer. Column chromatography was carried out on Si gel (230-400 mesh, Aldrich). TLC analyses were performed on a precoated Si gel W/UV indicator (Aldrich) and visualized by exposure to shortwavelength UV $\left(\lambda_{\max }=254\right)$ and/or by spraying with a mixture of vanillin-perchloric acid-EtOH followed by heating.

Plant material. Plant material of A. glazioviana was collected in January 1997, in Cristais, Ceará State, Brazil, and identified by botanists of the Departamento de Biologia da Universidade Federal do Ceará. A voucher specimen (\# 18639) is deposited at the Herbarium Prisco Bezerra.

Isolation and identification. Dried and powdered heartwood of A. glazioviana $(2.2 \mathrm{Kg})$ was exhaustively extracted with EtOH at room temperature. The EtOH extract was dried under reduced pressure to yield (149 g) and than was subjected to chromatography over Si gel using organic solvents in growing polarities, to afford the fractions: hexane $(1.3 \mathrm{~g}), \mathrm{CHCl}_{3}(76.0 \mathrm{~g})$, EtOAc (28.0 g) and $\mathrm{MeOH}(32.0 \mathrm{~g})$. Repeated chromatography analysis of $\mathrm{CHCl}_{3}$ and EtOAc fractions over silica gel using hexane and EtOAc as eluent, allowed the isolation of compounds 1, 2 and 3. Structure elucidation of all substances was accomplished by spectroscopic methods, including bidimensional NMR experiments and comparison with literature data. ${ }^{6,7}$ Isolated compounds 1, 2 and 3 were used as reference standard substances.

Glaziovianol 1. m.p. over $300^{\circ} \mathrm{C} .{ }^{1} \mathrm{H} \mathrm{NMR}\left(500 \mathrm{MHz}, \mathrm{CDCl}_{3}\right) \delta 0.90(3 \mathrm{H}, \mathrm{s}, \mathrm{H}-12), 2.00(1 \mathrm{H}, \mathrm{d}$, $J=16.5, \mathrm{H}-9), 2.00$ (1H, m, H-6), 2.10 (1H, d, $J=3.3, \mathrm{H}-10 \mathrm{a}), 2.30$ (1H, m, H-7), 2.30 (1H, t, $J$ =14.2, H-6), $2.60(1 \mathrm{H}, \mathrm{m}, \mathrm{H}-7), 2.90(1 \mathrm{H}, \mathrm{d}, J=16.5, \mathrm{H}-9), 3.8(2 \mathrm{H}, \mathrm{sl}, \mathrm{H}-11), 5.00(1 \mathrm{H}, \mathrm{d}, J=$ 3.3, H-10), $5.20(1 \mathrm{H}, \mathrm{s}, \mathrm{OH}), 6.49(1 \mathrm{H}, \mathrm{d}, J=8.2, \mathrm{H}-3), 6.50(1 \mathrm{H}, \mathrm{d}, J=8.2, \mathrm{H}-2), 8.40(1 \mathrm{H}, \mathrm{s}$, $\mathrm{OH}), 8.60(1 \mathrm{H}, \mathrm{s}, \mathrm{OH}) .{ }^{13} \mathrm{C}$ NMR $\left(125 \mathrm{MHz}, \mathrm{CDCl}_{3}\right) \delta 19.5(\mathrm{C}-12), 32.6(\mathrm{C}-6), 33.0(\mathrm{C}-9), 35.8$ (C-7), 41.6 (C-8a), 53.1 (C-10a), 73.3 (C-10), 78.9 (C-5), 82.3 (C-11), 113.2 (C-3), 115.4 (C-2), 121.5 (C-4a), 123.3 (C-9a), 148.0 (C-1), 150.0 (C-4), 215.1 (C-8). IR (KBr) cm- ${ }^{1}$ : 3500, 3000, 1698, 1540, 1483, 1450. Mass spectrum m/z, $70 \mathrm{eV}(\%): 290\left(\mathrm{M}^{+}, 75\right), 259(18), 175(100)$, 160(15).

Oncocalyxone A 2. m.p. $209-211{ }^{\circ} \mathrm{C} .{ }^{1} \mathrm{H}$ NMR $\left(500 \mathrm{MHz}, \mathrm{CDCl}_{3}\right) \delta 0.73(3 \mathrm{H}, \mathrm{s}, \mathrm{H}-12), 2.34$ (1H, d, $J=18.4, \mathrm{H}-9), 2.52$ (1H, d, $J=17.2, \mathrm{H}-7), 2.60$ (1H, dd, $J=17.2,3.9, \mathrm{H}-7), 2.90$ (d, $J=$ 18.4, H-9), 3.55 (1H, s, H-8), 3.73 (3H, s, $\left.\mathrm{CH}_{3} \mathrm{O}\right), 4.16(2 \mathrm{H}, \mathrm{s}, \mathrm{H}-11), 4.88(1 \mathrm{H}, \mathrm{t}, J=5.2, \mathrm{OH})$, $4.93(1 \mathrm{H}, \mathrm{d}, J=4.5, \mathrm{OH}), 6.00(1 \mathrm{H}, \mathrm{s}, \mathrm{H}-3), 6.02(1 \mathrm{H}, \mathrm{d}, J=3.9, \mathrm{H}-6), 6.48(1 \mathrm{H}, \mathrm{s}, \mathrm{H}-10) .{ }^{13} \mathrm{C}$ NMR (125 MHz, $\left.\mathrm{CDCl}_{3}\right) \delta 20.9$ (C-12), 28.8 (C-9), $31.6(\mathrm{C}-7), 38.9(\mathrm{C}-8 \mathrm{a}), 56.4\left(\mathrm{CH}_{3} \mathrm{O}\right), 61.3$ (C-11), 69.7 (C-8), 106.0 (C-3), 111.5 (C-10), 128.1 (C-6), 132.7 (C-9a), 134.2 (C-4a), 135.1 (C10a), 146.4 (C-5), 159.5 (C-2), 180.9 (C-1), 184.9 (C-4). IR (KBr) cm ${ }^{-1}$ : 3430, 3380, 1645, 1625 , 
1570, 1485, 970, 845. Mass spectrum m/z, $70 \mathrm{eV}(\%): 302\left(\mathrm{M}^{+}, 50\right), 284(41), 171(22), 128(31)$, $115(31)$.

Oncocalyxone C 3. m.p. $111-113{ }^{\circ} \mathrm{C} .{ }^{1} \mathrm{H}$ NMR (500 MHz, $\left.\mathrm{CDCl}_{3}\right) \delta 1.05(3 \mathrm{H}, \mathrm{s}, \mathrm{H}-12), 1.15$ $\left(3 \mathrm{H}, \mathrm{t}, J=7.0, \mathrm{CH}_{3} \mathrm{CH}_{2} \mathrm{O}\right), 1.50(1 \mathrm{H}, \mathrm{m}, \mathrm{H}-6), 1.57(1 \mathrm{H}, \mathrm{m}, \mathrm{H}-7), 1.62(1 \mathrm{H}, \mathrm{m}, \mathrm{H}-5), 1.79(1 \mathrm{H}$, m, H-6), 1.94 (1H, m, H-7), 2.19 (1H, m, H-10a), 2.35 (1H, d, J = 17.0, H-9), 2.48 (1H, d, J= 17.0, H-9), $3.46\left(1 \mathrm{H}, \mathrm{m}, \mathrm{OCH}_{2} \mathrm{CH}_{3}\right), 3.55(1 \mathrm{H}, \mathrm{dd}, J=10.7,4.7, \mathrm{H}-8), 3.80\left(3 \mathrm{H}, \mathrm{s}, \mathrm{CH}_{3} \mathrm{O}\right), 3.85$ $\left(1 \mathrm{H}, \mathrm{m}, \mathrm{OCH}_{2} \mathrm{CH}_{3}\right), 4.87(1 \mathrm{H}, \mathrm{d}, J=4.2, \mathrm{H}-11), 5.10(1 \mathrm{H}, \mathrm{d}, J=7.7, \mathrm{H}-10), 5.94$ (1H, s, H-3). ${ }^{13} \mathrm{C} \mathrm{NMR}\left(125 \mathrm{MHz}, \mathrm{CDCl}_{3}\right) \delta 15.5\left(\mathrm{OCH}_{2} \mathrm{CH}_{3}\right), 22.6(\mathrm{C}-6), 24.2(\mathrm{C}-9), 24.3(\mathrm{C}-12), 31.3(\mathrm{C}-7)$, 37.9 (C-8a), $43.7(\mathrm{C}-5), 46.6(\mathrm{C}-10 \mathrm{a}), 56.6\left(\mathrm{CH}_{3} \mathrm{O}\right), 63.6\left(\mathrm{OCH}_{2} \mathrm{CH}_{3}\right), 71.2(\mathrm{C}-10), 77.8(\mathrm{C}-8)$, 103.5 (C-11), 108.3 (C-3), 138.5 (C-9a), 139.3 (C-4a), 158.9 (C-2), 183.3 (C-1), 187.1 (C-4). IR $(\mathrm{KBr}) \mathrm{cm}^{-1}: 1640,1600,1220,1080$. Mass spectrum m/z, $70 \mathrm{eV}$ (\%): 348 (absent), 303 (8), 274(65), 256(17), 241(27).

Standard solutions and calibration curve. The solution standards were prepared by serial dilutions of the stock solution $1000 \mathrm{mg} / \mathrm{L}$, prepared with the isolated compounds, in $\mathrm{CH}_{3} \mathrm{CN} / \mathrm{H}_{2} \mathrm{O}$ $(1: 1, \mathrm{v} / \mathrm{v})$. A $20 \mu \mathrm{L}$ volume of each solution was filtered and then injected into the column. Peak areas of the chromatograms were plotted against concentrations $(\mathrm{mg} / \mathrm{mL})$ of solution injected. Results were expressed as the average of two injections. Calibration curves were obtained by plotting the ratios of the integrated peak areas at the maximum UV absorption, $280 \mathrm{~nm}$, for each compound versus concentration $(\mathrm{mg} / \mathrm{L})$ by performing linear regression analysis. ${ }^{13}$ Quantification was made by external calibration with correlation coefficients, $r$, of 0.999 for each analyzed compound. Identification of the cordiachromes peaks in the extracts was accomplished by comparison with the retention time of standard solutions injected in the same conditions.

\section{Acknowledgements}

The authors are grateful to the Brazilian Agencies FUNCAP, CNPq, CAPES and PRONEX for financial support.

\section{References}

1. Braga, R. Plantas do Nordeste Especialmente do Ceará, Ed. Universitaria da UFRNMossoró, Brasil, 1976.

2. Pessoa, O. D. L.; Lemos, T. L. G. Rev. Bras. Farm. 1997, 78, 9.

3. Costa, G. M.; Lemos, T. L. G.; Pessoa, O. D. L.; Monte, F. J. Q.; Braz-Filho, R. J. Nat. Prod. 1999, 62, 1044.

4. Pessoa, O. D. L.; Lemos, T. L. G.; Silveira, E. R.; Braz-Filho, R. Nat. Prod. Lett. 1993, 2, 145. 
5. Pessoa, O. D. L.; Lemos, T. L. G.; Carvalho, M. G.; Braz-Filho, R. Phytochemistry 1995, 40, 1777.

6. Moir, M.; Thomson, R. H. J. Chem. Soc., Chem. Comm. 1972, 363.

7. Moir, M.; Thomson, R. H. J. Chem. Soc., Perkin I 1973, 1352.

8. Leyva, A.; Pessoa, C.; Boogaerdt, F.; Sokaroski, R.; Lemos, T. L. G.; Wetmore, L.A.; Hukuta, R. R.; Moraes, M. O. Anticancer Res. 2000, 20, 1029.

9. Ferreira, M. A. D.; Nunes, O. D. R. H.; Fujimura, A. H. Y.; Pessoa, O. D. L.; Lemos, T. L. G.; Viana, G. S. B. Res. Comm. Mol. Pathol. and Pharmacol. 1999, $106,97$.

10. Costa-Lotufo, L.V.; Ferreira, M.A.D.; Lemos, T.L.G.; Pessoa, O.D.L.; Viana, G.S.B. and Cunha, G.M.A. Braz. J. Med. Biol. Res. 2002, 35, 930.

11. Ferreira, M.A.D.;Nunes, O.D.R.H.; Leal, L.K.A.M.; Pessoa, O.D.L.; Lemos, T.L.G.; Biol. Pharm. Bull. 2003, 26, 595.

12. Bozan, B.; Baser, K. H. C.; Kara, S. J. Chromatogr. A 1997, 782, 133.

13. Meyer, V.R. Practical High-Performance Liquid Chromatography; $2^{\text {nd }}$ Edn. John Wiley \& Sons: New York, USA, 1993. 